\title{
Gene Action Studies in the Inheritance of Economic Traits in Diallel Cross of Lentil (Lens culinaris Medik)
}

\author{
Fahim Abbas ${ }^{1}$, Asim Riaz ${ }^{2}$, Tanzeela Zafar ${ }^{3}$, Muhammad Hassan", \\ Hafiz Muhammad Imran Umar4, Javed Hassan ${ }^{4}$, Waseem Alam4, Saleh Muhammad5, \\ Mudassir Mahmood5, Hamza Sohail', Usman Ali Tiwana7, Muhammad Tayyab Iqbal", \\ Muhammad Bilal ${ }^{8}$ \\ ${ }^{1}$ Nanjing Agriculture University, Nanjing, China \\ ${ }^{2}$ Department of Pharmacy Health and Well-Being, University of Sunderland, Sunderland, UK \\ ${ }^{3}$ Centre of Agricultural Biochemistry and Biotechnology, Faculty of Agriculture, University of Agriculture, \\ Faisalabad, Pakistan \\ ${ }^{4}$ Department of Plant Breeding \& Genetics, Bahauddin Zakariya University, Multan, Pakistan \\ ${ }^{5}$ Department of Entomology, Bahauddin Zakariya University, Multan, Pakistan \\ ${ }^{6}$ Department of Horticulture, Bahauddin Zakariya University, Multan, Pakistan \\ ${ }^{7}$ Arid Zone Research Institute, Bahawalpur, Pakistan \\ ${ }^{8}$ Department of Plant Breeding \& Genetics, PMAS-UAA, Rawalpindi, Pakistan \\ Email: "famiszd@gmail.com
}

Received 16 November 2015; accepted 11 April 2016; published 14 April 2016

Copyright ( 2016 by authors and Scientific Research Publishing Inc.

This work is licensed under the Creative Commons Attribution International License (CC BY).

http://creativecommons.org/licenses/by/4.0/

c) (i) Open Access

\section{Abstract}

The present study was conducted in $4 \times 4$ half diallel cross fashion using the genotypes named as NL-2002, NL-2006, Punjab Masoor-2009 and Markaz-2009 for the evaluation of gene action in the inheritance of economic traits of lentil by following the Griffing (1956) Method of analysis. Minirap 13.1 Copyright ${ }^{\odot}$ 2000, Minitab inc. Method II, Model I was used for the analysis and gene action was computed by variance component analysis using Mixed Model with GLM (general linear model) procedure. The $F_{1}$ direct crosses along with the parental genotypes were then evaluated by framing the experiment in RCBD in 3 replications. The data were recorded for the characters which are under the study are, plant height $(\mathrm{cm})$, number of primary branches, number of secondary branches, number of pods per plant, number of seed per pod, seed yield per plant, biomass (gram), 100 seeds weight (gram), harvest index (\%), yield per plant. The simple ANOVA for all the characters revealed that difference among genotypes was highly significant. As significant differences were present between the genotypes, it permitted subsequent analysis of the data. The

"Corresponding author. 
Combining Ability (CA) results showed that value of variance for GCA (General Combining Ability) was significantly higher than that of those of the values of variance of SCA (Specific Combining Ability). Hence current results clearly depicted the role of additive type of gene action governing the characters under study.

\section{Keywords}

\section{Lentil, Diallel, Gene Action Studies}

\section{Introduction}

Lentil (Lens culinaris Medik.) is locally known as Masoor, having ploidy level 2n $=2 \mathrm{x}=14$ self-pollinated autogamous specie. Owing to small size of floral structure, self fertility is dominated in lentil. It is the $2^{\text {nd }}$ major Rabi pulse crop both in quality and quantity after chickpea. Lentil is a protein rich (22\% - 35\%), source of crucial amino acids (lysine, tryptophan) soluble and dietary fiber, minerals and vitamins (vitamin A and B). Lentil proteins have significant amount of, limiting amino acid in the cereals [1]. In addition to this, medical attributes are associated to it, uses in the remedy of constipation and other intestinal afflictions [2]. Being a legumimous crop, it has a unique ability to fix atmospheric nitrogen and more than $85 \%$ nitrogen requirements of the crop can be assembled into available from by the bacterial symbiosis [3]. In Pakistan, its area of production is decreasing at the alarming rate, considerable reduction in its area from 62,500 hectare to 31,000 hectares and its production from 35,000 tons to 6000 tons [4], putting pressure to fulfill domestic requirements by its heavy import posing huge burden on the rational exchequer from last 10 years, that's why market prices comparatively are eminent which lead to low/capita consumption. Hence its production should be increased by three times at the least to save the money which is now spent on its import and meet the demand of increasing population.

Genetic improvement on the lentil crop has been very melioration and has lacked institutional support. It is imperative to initiate research with the intention of obtaining more productive high-yielding cultivars, particularly through breeding (exploiting local germplasm). Focusing attention on yield and its associated characters, efforts should also be diverted for its different agro-ecological considerations and farming systems. Genetic variance within the populations of crop species is a major concern of plant breeders and geneticists [5]. Quantitative attributes render an approximate of genetic diversity; breeders must have potential of selecting the accession that most probably possesses the trait of concern.

The present research work was carried out considering the above facts with focus on objectives:

- To access component of variance for type of gene action estimation.

- To access the best combining parents out of four native varieties of Lentil, the estimates would be exploited for further breeding programs.

- To produce better lines regarding the high yield for further breeding program of Lentil crop.

\section{Materials and Methods}

The study was carried out at the experimental area of Department of Plant Breeding \& Genetics, Faculty of Agricultural Science, \& Technology, Bahauudin Zakariya University in Multan. Soil status of experimental farm area is given below in Table 1.

\subsection{Collection of Genotypes}

The seeds of four approved genotypes of lentils named as NL-2002, NL-2006, Punjab Masoor-2009 and Markaz-2009 were procured from (NIAB Faisalabad).

All genotypes were sown in the field during spring 2011 and all possible crosses were attempted are listed below in Table 2.

\subsection{Crossing Procedure}

In order to gain the high success rate of artificially induce hybridization only large floral buds were selected. 
Table 1. Soil status of experimental farm area.

\begin{tabular}{cc}
\hline PH (slightly inclined towards alkalinity) & 8.0 \\
Electrical conductivity & 2.8 \\
Organic matter \%age & 0.7 \\
Available nitrogen & $2 \mathrm{ppm}$ \\
Phosphorus & $3 \mathrm{ppm}$ \\
Potassium & $4 \mathrm{ppm}$ \\
\hline
\end{tabular}

\begin{tabular}{cc} 
Table 2. Possible crosses between genotypes. \\
\hline 1 & Crosses \\
\hline 2 & NL-2002 $\times$ NL-2006 \\
3 & NL-2002 $\times$ Punjab Masoor-2009 \\
4 & NL-2002 $\times$ Markaz-2009 \\
5 & NL-2006 × Punjab Masoor-2009 \\
6 & NL-2006 × Markaz-2009 \\
\hline
\end{tabular}

Furthermore, lateral buds were selected instead of terminal ones since the success is generally reported to be high with lateral buds. Selection of such flowers was made which belonged to a particular genotype that had not been self-pollinated and was quite young i.e. the pollens were in the granular form not of powdery form. Subsequently, the sepals were removed followed by removal of anthers containing pollen grains. After emasculation, young flowers of the other genotype containing pollens in powdery form were selected, their sepals and petals were removed around the petioles and finally cutting the end of petioles. Pollen grains were allowed to drain out into the ovary of the tagged flower by pushing its petals aside and the pollinated flower was finally closed. After pollination the solution of Gibberelic acid $\left(10\right.$ gm per 1 liter of $\left.\mathrm{H}_{2} \mathrm{O}\right)$ is sprayed on crossed plants to recover the injury to plants by crossing equipments. When crop reached on physically maturity, crossed pods were carefully harvested and seeds were threshed manually.

At next growing season the $\mathrm{F}_{0}$ seed along with the parental genotype were sown in Randomized Complete Block Design (RCBD) with three Replications to demonstrate the $\mathrm{F}_{1}$ generation. Ten to eleven lines, with line to line distance of 1 foot, line length of 10 foot, plant to plant distance of 4 inches and Path length 4 feet. The four genotypes were directly crossed. In each cross, 45 to 90 flowers were pollinated. The 90 flowers of each crosscombination were supposed to be completed in a 10-days time period thus leading to 9 crosses in every 24 hours with 3 crosses from each time interval treatment.

\section{Results and Discussion}

\subsection{Plant Height}

The ANOVA (Analysis of variance) for plant height showed that mean squares for ten genotypes (six crosses and four parents) were highly significant $(\mathrm{P} \leq 0.00)$, which in turn indicated that there were variations in the values for this characters (Table 3). Further analysis of data (as depicted in Table 4) revealed that the values of variance for GCA were rather higher (11.84) than those of SCA (Specific Combining Ability) (5.16). This confirms the role of additive gene effect $\left(\mathrm{V}_{\mathrm{A}}=5.16, \sigma^{2} \mathrm{a}=12.9307 \pm 1.07\right)$ in this character. Similar results were suggested by [6] and [7].

The parents were compared for GCA for plant height character (Table 5). Subsequent analysis revealed that 3 parents, NL-2006 (0.22), Punjab Masoor-2009 (2.54) and Markaz-2009 (2.46) depicted positive values and proved out to have the best GCA values for plant height. The remaining parent showed negative value i.e. NL2002 (-5.22) and clearly had lower GCA for plant height. 
For plant height, the potential of parents was analyzed for their specific combinations. The resulting comparisons are shown here in Table 6. Out of the total six crosses, 5 combinations, namely, NL-2002 $\times$ NL-2006 (4.56), NL-2002 × Punjab Masoor-2009 (1.90), NL-2006 × Punjab Masoor-2009 (1.13), NL-2006 × Markaz2009 (0.21) and Punjab Masoor-2009 $\times$ Markaz-2009 (1.88), yielded positive values for plant height. The remaining Crosse NL-2002 × Markaz-2009 (-1.68) had shown comparatively negative values.

Table 3. Analysis of variance of plant height in 10 genotypes of Lens culinaris Medik.

\begin{tabular}{ccccc}
\hline Source of variation & d.f & Sum of squares & Mean squares & F. Ratio \\
\hline Replication & 2 & 21.11 & 10.55 & $0.97^{\mathrm{NS}}$ \\
Genotypes & 9 & 875.98 & 97.33 & $8.98^{* *}$ \\
Error & 18 & 195.07 & 10.84 & \\
\hline
\end{tabular}

NS $=$ Non. Significant $(\mathrm{P}>0.05),{ }^{* *}=$ Highly Significant $(\mathrm{P}<0.05)$.

Table 4. Combining ability analysis of plant height in 10 genotypes of Lens culinaris Medik.

\begin{tabular}{ccccc}
\hline Source of variation & d.f & Mean square & $\sigma^{2}$ due to & Genetic effects \\
\hline GCA & 3 & 79.79 & 11.84 & $\mathrm{~V}_{\mathrm{A}}=5.16$ \\
SCA & 6 & 8.77 & 5.16 & $\mathrm{~V}_{\mathrm{D}}=2.29$ \\
Error & 18 & 3.61 & & \\
\hline
\end{tabular}

Table 5. Means, general and specific combining ability effects of plant height of 4 parents and 6 crosses.

\begin{tabular}{ccc}
\hline Parents & Means & GCA \\
\hline NL-2002 & 31.60 & -5.22 \\
NL-2006 & 41.93 & 0.22 \\
Punjab Masoor-2009 & 47.07 & 2.54 \\
Markaz-2009 & 49.16 & 2.46 \\
S.E. (gi-gj) & & 1.09 \\
\hline Crosses & Means & SCA \\
\hline NL-2002 $\times$ NL-2006 & 44.00 & 4.56 \\
NL-2002 $\times$ Punjab Masoor-2009 & 43.67 & 1.90 \\
NL-2002 $\times$ Markaz-2009 & 40.00 & -1.68 \\
NL-2006 $\times$ Punjab Masoor-2009 & 48.33 & 1.13 \\
NL-2006 $\times$ Markaz-2009 & 47.33 & 0.21 \\
Punjab Masoor-2009 $\times$ Markaz-2009 & 51.33 & 1.88 \\
S.E. (sij-sik) & & 2.45 \\
\hline
\end{tabular}

S.E. $($ gi-gj) = standard error for general combining ability and S.E. (sij-sik) = standard error for specific combining ability, applicable for all subsequent tables.

Table 6. Estimate of component of genetic variance in plant height of Lens culinaris Medik.

\begin{tabular}{ccc}
\hline Trait & $\sigma^{2} \mathrm{a}$ & $\sigma^{2} \mathrm{e}$ \\
\hline Plant height & $12.930 \pm 1.07$ & $14.457 \pm 2.46$
\end{tabular}

$\sigma^{2} \mathrm{a}=$ variance due to additive gene effect; $\sigma^{2} \mathrm{e}=$ variance due to environmental effect. 


\subsection{Primary Branches}

Variation was pretended by non-additive gene effects $\left(V_{D}=0.16, \sigma^{2} e=0.273 \pm 2.47\right.$ (Table 7, Table 8) for this character largely due to lower Combining Ability (0.03) as compared to the Specific Combining Ability (SCA) (0.19). Similar kinds of results were reported by [8].

Further comparison of parents for GCA (Table 9) revealed that that two parents, NL-2006 (0.25) and Punjab Masoor-2009 (0.19) showed positive values while the remaining 2 parents had negative values i.e. NL-2002 $(-0.36)$ and Markaz-2009 (-0.07). The potential of parents was analyzed for combinations (Table 9). Out of the six crosses, 4crosses (NL-2002 $\times$ Punjab Masoor-2009 (0.44), NL-2002 × Markaz-2009 (0.03), NL-2006 × Punjab Masoor-2009 (0.84) and PunjabMasoor-2009 $\times$ Markaz-2009 (0.15) had significantly positive numerical values while the rest of the crosses (NL-2002 × NL-2006 (-0.28) and NL-2006 × Markaz-2009 (-0.23) had otherwise result, showing negative values and poor SCA effects on Primary branches.

\subsection{Secondary Branches}

Significant differences were present (for secondary branches) between the genotypes then it permitted further

Table 7. Combining ability analysis of primary branches in 10 genotypes of Lens culinaris Medik.

\begin{tabular}{ccccc}
\hline Source of variation & d.f & Mean squares & $\sigma^{2}$ due to & Genetic effects \\
\hline GCA & 3 & 0.46 & 0.03 & $\mathrm{~V}_{\mathrm{A}}=0.19$ \\
SCA & 6 & 0.266 & 0.19 & $\mathrm{~V}_{\mathrm{D}}=0.16$ \\
Error & 18 & 0.06 & & \\
\hline
\end{tabular}

Table 8. Estimate of component of genetic variance in primary branches of Lens culinaris Medik.

\begin{tabular}{ccc}
\hline Trait & $\sigma^{2} \mathrm{a}$ & $\sigma^{2} \mathrm{e}$ \\
\hline Primary branches & $0.314 \pm 1.17$ & $0.273 \pm 2.47$ \\
\hline
\end{tabular}

$\sigma^{2} \mathrm{a}=$ variance due to additive gene effect; $\sigma^{2} \mathrm{e}=$ variance due to environmental effect.

Table 9. Means, general and specific combining ability effects of primary branches of 4 parents and 6 crosses.

\begin{tabular}{ccc}
\hline Parents & Means & GCA \\
\hline NL-2002 & 2.25 & -0.36 \\
NL-2006 & 3.40 & 0.25 \\
Punjab Masoor-2009 & 2.73 & 0.19 \\
Markaz-2009 & 2.95 & -0.072 \\
S.E. (gi-gj) & & 0.15 \\
\hline Crosses & Means & SCA \\
\hline NL-2002 $\times$ NL-2006 & 2.66 & -0.28 \\
NL-2002 $\times$ Punjab Masoor-2009 & 3.33 & 0.44 \\
NL-2002 $\times$ Markaz-2009 & 2.66 & 0.03 \\
NL-2006 $\times$ Punjab Masoor-2009 & 4.33 & 0.84 \\
NL-2006 $\times$ Markaz-2009 & 3.00 & -0.23 \\
Punjab Masoor-2009 $\times$ Markaz-2009 & 3.33 & 0.15 \\
S.E. (sij-sik) & & 0.33 \\
\hline
\end{tabular}


analysis of data succeeding combining ability analysis, and the results of analysis are awarded in (Table 10). The variance resulting from General Combining Ability was higher (24.38) than that because of Specific Combining Ability (-0.98), this shows that variation was pretended by additive gene effects $\left(\mathrm{V}_{\mathrm{A}}=-0.98, \sigma^{2} \mathrm{a}=\right.$ $33.2715 \pm 1.24$ ). Our findings contradicted the research work of [9] and [2] while the similar results were suggested by [10] and [11]. Each of the parents was compared for its general combining ability for the character secondary branches (Table 11) but further analysis brought out that three parents, NL-2006 (3.38), Punjab Masoor-2009 (0.57) and Markaz-2009 (3.32) accomplished positive values and exhibited to be the best general combiner for the character secondary branches and the remaining one parent attained negative value i.e. NL-2002 (-7.27) and clearly showed poor general combining ability for secondary branches. The potential of parents was analyzed for their specific combinations, and the comparisons are given in (Table 12). The ordering showed that out of six crosses, four combination achieved positive values, namely, NL-2002 × NL-2006 (0.67), NL-2002 × Punjab Masoor-2009 (1.15), NL-2006 × Punjab Masoor-2009 (1.16) and NL-2006 × Markaz-2009 (3.41) for secondary branches and showed to be the best general combiner. The remaining Crosses NL-2002 $\times$ Markaz-2009 (-1.60) and Punjab Masoor-2009 × Markaz-2009 (-0.78) attained negative values and showed poor specific combining ability effects for secondary branches.

Table 10. Combining ability analysis of secondary branches in 4 genotypes of Lens culinaris Medik.

\begin{tabular}{ccccc}
\hline Source of variation & d.f & Mean squares & $\sigma^{2}$ due to & Genetic effects \\
\hline GCA & 3 & 151.39 & 24.38 & $\mathrm{~V}_{\mathrm{A}}=-0.98$ \\
SCA & 6 & 4.27 & -0.98 & $\mathrm{~V}_{\mathrm{D}}=-24.90$ \\
Error & 18 & 5.25 & & \\
\hline
\end{tabular}

Table 11. Means, general and specific combining ability effects of secondary branches of 4 parents and 6 crosses.

\begin{tabular}{ccc}
\hline Parents & Means & GCA \\
\hline NL-2002 & 6.90 & -7.27 \\
NL-2006 & 25.70 & 3.38 \\
Punjab Masoor-2009 & 21.94 & 0.57 \\
Markaz-2009 & 27.68 & 3.32 \\
S.E. (gi-gj) & & 1.32 \\
\hline Crosses & Means & SCA \\
\hline NL-2002 $\times$ NL-2006 & 18.33 & 0.67 \\
NL-2002 $\times$ Punjab Masoor-2009 & 16.00 & 1.15 \\
NL-2002 $\times$ Markaz-2009 & 16.00 & -1.60 \\
NL-2006 $\times$ Punjab Masoor-2009 & 26.67 & 1.16 \\
NL-2006 $\times$ Markaz-2009 & 31.67 & 3.41 \\
Punjab Masoor-2009 $\times$ Markaz-2009 & 24.67 & -0.78 \\
S.E. (sij-sik) & & 2.96 \\
\hline
\end{tabular}

Table 12. Estimate of component of genetic variance in secondary branches of Lens culinaris Medik.

\begin{tabular}{ccc}
\hline Trait & $\sigma^{2} \mathrm{a}$ & $\sigma^{2} \mathrm{e}$ \\
\hline Secondary branches & $33.271 \pm 1.24$ & $23.563 \pm 2.48$ \\
\hline
\end{tabular}

$\sigma^{2} \mathrm{a}=$ variance due to additive gene effect; $\sigma^{2} \mathrm{e}=$ variance due to environmental effect. 


\subsection{Number of Pods per Plant}

The variance resulting from General Combining Ability (for number of pods per plant) was higher (1915.38) than that of Specific Combining Ability (327.27), showed that variation was acted by additive gene effects $\left(\mathrm{V}_{\mathrm{A}}\right.$ $=327.27, \sigma^{2} \mathrm{a}=3382.091 \pm 1.29$ Table 13 , Table 14). These results are in line with the findings of [12]. Table 14 shows that NL-2006 (31.18), Punjab Masoor-2009 (3.35) and Markaz-2009 (30.57) accomplished positive values and exhibited to be the best general combiner for the character under study. Remaining one parent attained negative value i.e. NL-2002 (-65.12) and clearly showed poor general combining ability for Number of pods per plant. Arrangement showed that out of six crosses, three combination achieved positive values, namely, NL-2002 × Punjab Masoor-2009 (23.81), NL-2006 × Punjab Masoor-2009 (25.51) and NL-2006 × Markaz-2009 (35.61) for Number of pods per plant and showed to be the best general combiner (Table 15). The remaining Crosses NL-2002 × NL-2006 (-2.69), NL-2002 × Markaz-2009 (-31.41) and Punjab Masoor-2009 × Markaz2009 (-17.22) attained negative values and showed poor specific combining ability effects for Number of pods per plant.

Table 13. Combining ability analysis of No. of pods per plant in 10 genotypes of Lens culinaris Medik.

\begin{tabular}{ccccc}
\hline Source of variation & d.f & Mean squares & $\sigma^{2}$ due to & Genetic effects \\
\hline GCA & 3 & $12,318.3$ & 1915.38 & $\mathrm{~V}_{\mathrm{A}}=327.27$ \\
SCA & 6 & 826.1 & 327.27 & $\mathrm{~V}_{\mathrm{D}}=5.85$ \\
Error & 18 & 498.8 & & \\
\hline
\end{tabular}

Table 14. Estimate of component of genetic variance in No. of pods per plant of Lens culinaris Medik.

\begin{tabular}{ccc} 
Trait & $\sigma^{2} \mathrm{a}$ & $\sigma^{2} \mathrm{e}$ \\
\hline No. of pods per plant & $3382.09 \pm 1.29$ & $1977.83 \pm 2.47$ \\
\hline
\end{tabular}

$\sigma^{2} \mathrm{a}=$ variance due to additive gene effect; $\sigma^{2} \mathrm{e}=$ variance due to environmental effect.

Table 15. Means, general and specific combining ability effects of No. of pods per plant of 4 parents and 6 crosses.

\begin{tabular}{ccc}
\hline Parents & Means & GCA \\
\hline NL-2002 & 53.20 & -65.12 \\
NL-2006 & 211.45 & 31.18 \\
Punjab Masoor-2009 & 168.94 & 3.35 \\
Markaz-2009 & 245.95 & 30.57 \\
S.E.(gi-gj) & & 12.89 \\
\hline Crosses & Means & SCA \\
\hline NL-2002 $\times$ NL-2006 & 141.67 & -2.69 \\
NL-2002 $\times$ Punjab Masoor-2009 & 140.3 & 23.81 \\
NL-2002 $\times$ Markaz-2009 & 112.3 & -31.41 \\
NL-2006 $\times$ Punjab Masoor-2009 & 238.3 & 25.51 \\
NL-2006 $\times$ Markaz-2009 & 275.6 & 35.61 \\
Punjab Masoor-2009 $\times$ Markaz-2009 & 195.0 & -17.22 \\
S.E.(sij-sik) & & 28.83 \\
\hline
\end{tabular}




\subsection{Number of Seed per Pod}

Non-additivegene effects $\left(\mathrm{V}_{\mathrm{D}}=-0.19, \sigma^{2} \mathrm{e}=0.042 \pm 2.46\right.$ Table 16 , Table 17) Similar results were suggested by [12]. NL-2002 (0.03) and NL-2006 (0.02), accomplished positive values and demonstrated to be the best general combiner for the character no. of seed per pod and the remaining one parent attained negative value i.e. Punjab Masoor-2009 (-0.03) and Markaz-2009 (-0.01) and clearly showed poor general combining ability for Number of seed per pod (Table 18). The potential of parents was analyzed for their specific combinations, and the comparisons are given in (Table 18). The ordering showed that out of six crosses, five combination achieved positive values these are, NL-2002 $\times$ NL-2006 (0.17), NL-2002 $\times$ Punjab Masoor-2009 (0.05), NL-2002 $\times$ Markaz-2009 (0.20) NL-2006 × Punjab Masoor-2009 (0.22) and NL-2006 × Markaz-2009 (0.04) for Plant height and showed to be the best general combiner. The remaining Crosse Punjab Masoor-2009 $\times$ Markaz-2009 $(-0.07)$ attained negative values and showed poor specific combining ability effects for Number of seed per pod.

\subsection{Biomass}

The variance resulting from General Combining Ability was higher (6.59) than that because of Specific Combining

Table 16. Combining ability analysis of No. of seed per pod in 10 genotypes of Lens culinaris Medik.

\begin{tabular}{ccccc}
\hline Source of variation & d.f & Mean squares & $\sigma^{2}$ due to & Genetic effects \\
\hline GCA & 3 & 0.004 & -0.01 & $\mathrm{~V}_{\mathrm{A}}=0.032$ \\
SCA & 6 & 0.04 & 0.03 & $\mathrm{~V}_{\mathrm{D}}=-0.19$ \\
Error & 18 & 0.01 & & \\
\hline
\end{tabular}

Table 17. Estimate of component of genetic variance in No. of seed per pod of Lens culinaris Medik.

\begin{tabular}{ccc} 
Trait & $\sigma^{2} \mathrm{a}$ & $\sigma^{2} \mathrm{e}$ \\
\hline No. of seed per pod & $0.004 \pm 0.28$ & $0.042 \pm 2.46$ \\
\hline
\end{tabular}

$\sigma^{2} \mathrm{a}=$ variance due to additive gene effect; $\sigma^{2} \mathrm{e}=$ variance due to environmental effect.

Table 18. Means, general and specific combining ability effects of No. of seed per pod of 4 parents and 6 crosses.

\begin{tabular}{ccc}
\hline Parents & Means & GCA \\
\hline NL-2002 & 1.63 & 0.03 \\
NL-2006 & 1.60 & 0.02 \\
Punjab Masoor-2009 & 1.62 & -0.03 \\
Markaz-2009 & 1.67 & -0.01 \\
S.E. (gi-gj) & & 0.05 \\
\hline Crosses & Means & SCA \\
\hline NL-2002 $\times$ NL-2006 & 2.00 & 0.17 \\
NL-2002 $\times$ Punjab Masoor-2009 & 1.83 & 0.05 \\
NL-2002 $\times$ Markaz-2009 & 2.00 & 0.20 \\
NL-2006 $\times$ Punjab Masoor-2009 & 2.00 & 0.22 \\
NL-2006 $\times$ Markaz-2009 & 1.83 & 0.04 \\
\hline Punjab Masoor-2009 $\times$ Markaz-2009 & 1.66 & -0.075 \\
S.E. (sij-sik) & & 0.12 \\
\hline
\end{tabular}


Ability (2.31), this shows that variation was pretended by additive gene effects $\left(\mathrm{V}_{\mathrm{A}}=2.31, \sigma^{2} \mathrm{a}=10.014 \pm 0.99\right.$ Table 19, Table 20). Similar results were suggested [13]. Each of the parents was compared for its general combining ability for the character Biomass. (Table 21) but further analysis brought out that three parents, NL-2006 (1.55), Punjab Masoor-2009 (1.29) and Markaz-2009 (1.29) accomplished positive values and exhibited to be the best general combiner for the character Biomass. Remaining one parent attained negative value i.e. NL-2002 (-4.14) and clearly showed poor general combining ability for Biomass. The potential of parents was analyzed for their specific combinations, and the comparisons are given in (Table 20) The ordering showed that out of six crosses, four combination achieved positive values, namely, NL-2002 × NL-2006 (1.51), NL$2002 \times$ Punjab Masoor-2009 (1.67), NL-2006 × Punjab Masoor-2009 (3.79) and NL-2006 × Markaz-2009 (0.33) for Biomass and showed to be the best general combiner. The remaining Crosse NL-2002 $\times$ Markaz-2009 $(-1.29)$ and Punjab Masoor-2009 × Markaz-2009 (-1.01) attained negative values and showed poor specific combining ability effects for Biomass.

\subsection{Seed Yield per Plant}

Variation was dominated by additive gene effects $\left(\mathrm{V}_{\mathrm{A}}=1.44, \sigma^{2} \mathrm{a}=0.050 \pm 1.29\right.$ Table 22, Table 23). Similar

Table 19. Combining ability analysis of biomass in 10 genotypes of Lens culinaris Medik.

\begin{tabular}{ccccc}
\hline Source of variation & d.f & Mean squares & $\sigma^{2}$ due to & Genetic effects \\
\hline GCA & 3 & 45.75 & 6.59 & $\mathrm{~V}_{\mathrm{A}}=2.31$ \\
SCA & 6 & 6.17 & 2.31 & $\mathrm{~V}_{\mathrm{D}}=2.85$ \\
Error & 18 & 3.87 & & \\
\hline
\end{tabular}

Table 20. Estimate of component of genetic variance in biomass of Lens culinaris Medik.

\begin{tabular}{ccc} 
Trait & $\sigma^{2} \mathrm{a}$ & $\sigma^{2} \mathrm{e}$ \\
\hline Biomass & $10.014 \pm 0.99$ & $15.466 \pm 2.49$ \\
\hline
\end{tabular}

$\sigma^{2} \mathrm{a}=$ variance due to additive gene effect; $\sigma^{2} \mathrm{e}=$ variance due to environmental effect.

Table 21. Means, general and specific combining ability effects of biomass of 4 parents and 6 crosses.

\begin{tabular}{ccc} 
Parents & Means & GCA \\
\hline NL-2002 & 4.83 & -4.14 \\
NL-2006 & 14.35 & 1.55 \\
Punjab Masoor-2009 & 14.42 & 1.29 \\
Markaz-2009 & 17.61 & 1.29 \\
S.E. (gi-gj) & & 1.13 \\
\hline Crosses & Means & SCA \\
\hline NL-2002 $\times$ NL-2006 & 12.99 & 1.51 \\
NL-2002 $\times$ Punjab Masoor-2009 & 12.89 & 1.67 \\
NL-2002 $\times$ Markaz-2009 & 9.91 & -1.29 \\
NL-2006 $\times$ Punjab Masoor-2009 & 20.70 & 3.79 \\
NL-2006 $\times$ Markaz-2009 & 17.23 & 0.33 \\
Punjab Masoor-2009 $\times$ Markaz-2009 & 15.63 & -1.01 \\
S.E. (sij-sik) & & 2.54 \\
\hline
\end{tabular}


results were suggested by [14]. NL-2006 (0.61), Punjab Masoor-2009 (0.39) and Markaz-2009 (1.31) accomplished positive values and exhibited to be the best general combiner for the character seed yield per plant (Table 24). Remaining one parent attained negative value i.e. NL-2002 (-2.30) and clearly showed poor general combining ability for seed yield per plant. Ordering showed that out of six crosses, four combination achieved positive values, namely, NL-2002 × NL-2006 (0.31), NL-2002 × Punjab Masoor-2009 (1.13), NL-2006 × Punjab Masoor-2009 (2.21) and NL-2006 $\times$ Markaz-2009 (0.86) for seed yield per plant and showed to be the best general combiner in (Table 24). The remaining two Crosses NL-2002 $\times$ Markaz-2009 (-1.22) and Punjab Masoor-2009 × Markaz-2009 (-0.59) attained negative values and showed poor specific combining ability effects for seed yield per plant.

\subsection{Seed Weight}

General Combining Ability was higher (0.03) than that of Specific Combining Ability (0.00) revealed that variation was pretended by additive gene effects $\left(\mathrm{V}_{\mathrm{A}}=0.00, \sigma^{2} \mathrm{a}=0.061 \pm 0.19\right.$ Table 25, Table 26). The results are in agreement with the findings of [15]. Each of the parents was compared for its general combining ability for the character hundred seed weight indicated that NL-2002 (0.25) accomplished positive values and exhibited to

Table 22. Combining ability analysis of seed yield per plant in 10 genotypes of Lens culinaris Medik.

\begin{tabular}{ccccc}
\hline Source of variation & d.f & Mean squares & $\sigma^{2}$ due to & Genetic effects \\
\hline GCA & 3 & 15.14 & 2.14 & $\mathrm{~V}_{\mathrm{A}}=1.44$ \\
SCA & 6 & 2.30 & 1.44 & $\mathrm{~V}_{\mathrm{D}}=1.48$ \\
Error & 18 & 0.86 & & \\
\hline
\end{tabular}

Table 23. Estimate of component of genetic variance in Seed yield per plant of Lens culinaris Medik.

\begin{tabular}{ccc} 
Trait & $\sigma^{2} \mathrm{a}$ & $\sigma^{2} \mathrm{e}$ \\
\hline Seed yield per plant & $0.050 \pm 1.29$ & $0.028 \pm 2.46$ \\
\hline
\end{tabular}

$\sigma^{2} \mathrm{a}=$ variance due to additive gene effect; $\sigma^{2} \mathrm{e}=$ variance due to environmental effect.

Table 24. Means, general and specific combining ability effects of Seed yield per plant of 4 parents and 6 crosses.

\begin{tabular}{|c|c|c|}
\hline Parents & Means & GCA \\
\hline NL-2002 & 2.92 & -2.30 \\
\hline NL-2006 & 7.18 & 0.61 \\
\hline Punjab Masoor-2009 & 7.06 & 0.39 \\
\hline Markaz-2009 & 10.74 & 1.31 \\
\hline S.E. (gi-gj) & & 0.53 \\
\hline Crosses & Means & SCA \\
\hline NL-2002 × NL-2006 & 6.26 & 0.31 \\
\hline NL-2002 × Punjab Masoor-2009 & 6.87 & 1.13 \\
\hline NL-2002 × Markaz-2009 & 5.43 & -1.22 \\
\hline NL-2006 × Punjab Masoor-2009 & 10.87 & 2.21 \\
\hline NL-2006 × Markaz-2009 & 10.43 & 0.86 \\
\hline Punjab Masoor-2009 × Markaz-2009 & 8.77 & -0.59 \\
\hline S.E. (sij-sik) & & 1.19 \\
\hline
\end{tabular}


be the best general combiner for the character hundred seed weight and remaining three parents attained negative value i.e. NL-2006 (-0.21), Punjab Masoor-2009 (-0.02) and Markaz-2009 (-0.03) and clearly showed poor general combining ability for character hundred seed weight. The potential of parents was assessed for their specific combinations, and the comparisons are given in (Table 27) the ordering showed that out of six crosses, three combinations achieved positive values, Namely, NL-2002 × Punjab Masoor-2009 (0.11), NL-2006 × Punjab Masoor-2009 (0.07), and Punjab Masoor-2009 $\times$ Markaz-2009 (0.09) for hundred seed weight and showed to be the best general combiner. The remaining Crosse NL-2002 $\times$ NL-2006 (-0.03), NL-2002 × Markaz-2009 $(-0.02)$ and NL-2006 $\times$ Markaz-2009 (-0.07) attained negative values and showed poor specific combining ability effects for hundred seed weight.

\subsection{Harvest Index}

Variation (for harvest index) was pretended by non-additive gene effects $\left(\mathrm{V}_{\mathrm{D}}=0.33, \sigma^{2} \mathrm{e}=15.907 \pm 2.48\right.$ Table 28, Table 29) owing to lower general Combining Ability was lower (3.75). Similar results were suggested by [16]. Comparison of parents for general combining ability for the character harvest index (Table 30) indicated that two parents, NL-2002 (0.52) and Markaz-2009 (3.31) accomplished positive values and exhibited to be the

Table 25. Combining ability analysis of 100 seed weight in 10 genotypes of Lens culinaris Medik.

\begin{tabular}{ccccc}
\hline Source of variation & d.f & Mean squares & $\sigma^{2}$ due to & Genetic effects \\
\hline GCA & 3 & 0.22 & 0.035 & $\mathrm{~V}_{\mathrm{A}}=0.00$ \\
SCA & 6 & 0.01 & 0.00 & $\mathrm{~V}_{\mathrm{D}}=16.37$ \\
Error & 18 & 0.01 & & \\
\hline
\end{tabular}

Table 26. Estimate of component of genetic variance of 100 seed weight of Lens culinaris Medik.

\begin{tabular}{ccc} 
Trait & $\sigma^{2} \mathrm{a}$ & $\sigma^{2} \mathrm{e}$ \\
\hline 100 Seed Weight & $0.061 \pm 0.19$ & $0.038 \pm 1.23$ \\
\hline
\end{tabular}

$\sigma^{2} \mathrm{a}=$ variance due to additive gene effect; $\sigma^{2} \mathrm{e}=$ variance due to environmental effect.

Table 27. Means, general and specific combining ability effects of 100 seed weight of 4 parents and 6 crosses.

\begin{tabular}{ccc}
\hline Parents & Means & GCA \\
\hline NL-2002 & 2.57 & 0.25 \\
NL-2006 & 1.68 & -0.21 \\
Punjab Masoor-2009 & 1.92 & -0.02 \\
Markaz-2009 & 2.04 & -0.03 \\
S.E. (gi-gj) & & 0.04 \\
\hline Crosses & Means & SCA \\
\hline NL-2002 $\times$ NL-2006 & 2.10 & -0.03 \\
NL-2002 $\times$ Punjab Masoor-2009 & 2.43 & 0.11 \\
NL-2002 $\times$ Markaz-2009 & 2.30 & -0.02 \\
NL-2006 $\times$ Punjab Masoor-2009 & 1.93 & 0.07 \\
NL-2006 $\times$ Markaz-2009 & 1.78 & -0.07 \\
Punjab Masoor-2009 $\times$ Markaz-2009 & 2.13 & 0.09 \\
S.E. (sij-sik) & & 0.01 \\
\hline
\end{tabular}


Table 28. Combining ability analysis of harvest index in 10 genotypes of Lens culinaris Medik.

\begin{tabular}{ccccc}
\hline Source of variation & d.f & Mean squares & $\sigma^{2}$ due to & Genetic effects \\
\hline GCA & 3 & 37.24 & 3.75 & $\mathrm{~V}_{\mathrm{A}}=11.16$ \\
SCA & 6 & 14.72 & 11.16 & $\mathrm{~V}_{\mathrm{D}}=0.33$ \\
Error & 18 & 3.56 & & \\
\hline
\end{tabular}

Table 29. Estimate of component of genetic variance in harvest index of Lens culinaris Medik.

\begin{tabular}{ccc} 
Trait & $\sigma^{2} \mathrm{a}$ & $\sigma^{2} \mathrm{e}$ \\
\hline Harvest Index & $11.511 \pm 1.02$ & $15.906 \pm 2.48$ \\
\hline
\end{tabular}

$\sigma^{2} \mathrm{a}=$ variance due to additive gene effect; $\sigma^{2} \mathrm{e}=$ variance due to environmental effect.

Table 30. Means, general and specific combining ability effects of harvest index of 4 parents and 6 crosses.

\begin{tabular}{ccc}
\hline Parents & Means & GCA \\
\hline NL-2002 & 59.95 & 0.52 \\
NL-2006 & 50.03 & -1.70 \\
Punjab Masoor-2009 & 49.02 & -2.13 \\
Markaz-2009 & 60.89 & 3.31 \\
S.E. (gi-gj) & & 1.09 \\
\hline Crosses & Means & SCA \\
\hline NL-2002 $\times$ NL-2006 & 48.89 & -4.72 \\
NL-2002 $\times$ Punjab Masoor-2009 & 53.49 & 0.31 \\
NL-2002 $\times$ Markaz-2009 & 54.79 & -3.82 \\
NL-2006 $\times$ Punjab Masoor-2009 & 53.62 & 2.66 \\
NL-2006 $\times$ Markaz-2009 & 61.18 & 4.78 \\
Punjab Masoor-2009 $\times$ Markaz-2009 & 56.03 & 0.06 \\
S.E. (sij-sik) & & 2.43 \\
\hline
\end{tabular}

best general combiner and the remaining two parents attained negative value i.e. NL-2006 (-1.70), Punjab Masoor-2009 (-2.13) and clearly showed poor general combining ability. In (Table 30) ordering showed that out of six crosses, four combination achieved positive values, namely, NL-2002 $\times$ Punjab Masoor-2009 (0.31), NL2006 × Punjab Masoor-2009 (2.66), NL-2006 × Markaz-2009 (4.78) and Punjab Masoor-2009 × Markaz-2009 (0.06) for harvest index and showed to be the best general combiner. The remaining two Crosses. NL-2002 $\times$ NL-2006 (-4.72) and NL-2002 $\times$ Markaz-2009 (-3.82) attained negative values and showed poor specific combining ability effects for the character harvest index.

\section{References}

[1] Ajmal, S.U., Zubair, M. and Anwar, M. (2007) Genetic Implication of Yield and Its Components in Mungbean Vigna radiata (L.) Wilczek. Pakistan Journal of Botany, 39, 1229-1236.

[2] Anbessa, Y., Warkentin, T., Vandenberg, A. and Ball, R. (2006) Inheritance of Time to Flowering in Chickpea in Short Season Temperate Environment. Journal of Heredity, 97, 55-61. http://dx.doi.org/10.1093/jhered/esj009

[3] Bisen, C.R., Tamar, J.S., Hivamunthy, R.B. and Kashayap, M.L. (1980) Response of Lentil Rhizobium Inoculation and Fertilization under Different Moisture Regimes. Mysore Journal of Agricultural Sciences, 14, 483-486. 
[4] Shakoor, U., Saboor, A., Ali, I. and Mohsin, A.Q. (2011) Impact of Climate Change on Agriculture: Empirical Evidence from Arid Region. Pakistan Journal of Agricultural Sciences, 48, 327-333.

[5] Hayward, M.D. and Breese, E.L. (1993) Population Structure and Variability. In: Hayward, M.D., Bosemark, N.O., Romayosa, I., Eds., Plant Breeding: Principles and Prospects, Chapman and Hall, London, 7-29. http://dx.doi.org/10.1007/978-94-011-1524-7 3

[6] Sharma, A., Singh, G., Singh, Y. and Sood, S. (2008) Detection of Genetic Components of Variation for Biometrical Traits in Garden Pea. International Journal of Vegetable Science, 14, 67-80. http://dx.doi.org/10.1080/19315260801890658

[7] Sultana, T., Ghafoor, A. and Ashraf, M. (2005) Genetic Divergence in Lentil Germplasm for Botanical Descriptors in Relation with Geographic Origin. Pakistan Journal of Botany, 37, 61-69.

[8] Malhotra, R.S. and Singh, K.B. (1989) Detection of Epistasis in Chickpea (Cicer arietinum L.). Euphytica, 40, 169172.

[9] Kidambi, S.P., Sandhd, T.S. and Bhullar, B.S. (1988) Genetic Analysis of Developmental Traits in Chickpea (Cicer arietinum L.). Plant Breeding, 101, 225-235. http://dx.doi.org/10.1111/j.1439-0523.1988.tb00291.X

[10] Dhaiwal, H.S. and Gill, A.S. (1973) Studies of Heterosis, Combining Ability and Inheritance of Yield and Yield Components in a Diallel Cross of Bengal Gram (Cicer aretinum L.). Theoretical and Applied Genetics, 43, 381-386. http://dx.doi.org/10.1007/BF00278176

[11] Kumar, J. and Rheenen, H.A. (2000) A Major Gene for Time of Flowering in Chickpea (Cicer arietinum L.). Journal of Heredity, 91, 67-68. http://dx.doi.org/10.1093/jhered/91.1.67

[12] Moll, R.H., Robinson, H.F. and Cockerham, C.O. (1960) Genetic Variability in Advance Generations of Crosses Two Open Pollinated Varieties of Lentil. Agronomy Journal, 52, 171-173. http://dx.doi.org/10.2134/agronj1960.00021962005200030015x

[13] Khan, I.A. and Malik, B.A. (1989) Grain and Biological Yield Association in Chickpea. Sarhad J. Agric. Res., 5, 373575.

[14] Oliveira Junior, A., Miranda, G.V. and Cruz, C.D. (1997) Evaluation of the Combining Ability of Dry Bean Cultivars Based on Unbalanced Circulating and Partial Diallel Crossing Systems. Revista Ceres, 44, 215-229.

[15] Islam, A.K.M.A. and Newaz, M.A. (2002) Combing Ability for Seed and Yield and Related Characters in Dry Bean (Phaseolus vulgaris L.) under Two Cultural Environments. Journal of the Asiatic Society of Bangladesh, Science, 28, 101-110.

[16] Zhu, H., Choi, D.R. and Shoemarker, C. (2005) Bridging Model and Crop Legumes through Comparative Genomics. Plant Physiology, 137, 1189-1196. http://dx.doi.org/10.1104/pp.104.058891 